Western University

Scholarship@Western

Civil and Environmental Engineering

Civil and Environmental Engineering

Publications

Department

2018

Seismic fragility assessment of superelastic shape memory alloy reinforced concrete shear walls

Emad A. Abraik

Western University

Maged A. Youssef

Western University, youssef@uwo.ca

Follow this and additional works at: https://ir.lib.uwo.ca/civilpub

Part of the Structural Engineering Commons

Citation of this paper:

Abraik, Emad A. and Youssef, Maged A., "Seismic fragility assessment of superelastic shape memory alloy reinforced concrete shear walls" (2018). Civil and Environmental Engineering Publications. 193.

https://ir.lib.uwo.ca/civilpub/193 


\title{
SEISMIC FRAGILITY ASSESSMENT OF SUPERELASTIC SHAPE MEMORY ALLOY REINFORCED CONCRETE SHEAR WALLS
}

\author{
Emad Abraik ${ }^{1}$, Maged Youssef ${ }^{2, *}$ \\ ${ }^{1}$ Graduate Student, Civil and Environmental Engineering, Western University, London, Ontario, Canada \\ ${ }^{2}$ Professor, Civil and Environmental Engineering, Western University, London, Ontario, Canada
}

\begin{abstract}
Mitigation of seismic damage can be achieved through self-centering techniques. One of the potential techniques involves the use of Superelastic Shape Memory Alloy (SE-SMA) bars in Reinforced Concrete (RC) structures. This study explores the use of such bars in the plastic-hinge regions of RC walls. The seismic performance and vulnerability of SE-SMA RC walls of ten- and twenty-story buildings are analytically assessed using fragility curves. The maximum inter-story drift, residual drift, and fragility are evaluated using multi strip analysis. The results clearly demonstrate the superior seismic performance of SE-SMA RC walls as compared to steel RC walls.
\end{abstract}

KEYWORDS: Shear wall; shape memory alloy; multi-strip analysis; fragility analysis; inter-story drift ratio; residual displacement

* Corresponding Author, Email: youssef@uwo.ca, Phone: 1-519-661-2111 Ext. 88661 


\section{INTRODUCTION}

The main function of reinforced concrete (RC) structural walls is to resist lateral loads. Extensive studies have been conducted to explore their behaviour under various load conditions $[1,2,3]$. The seismic design philosophy, which aims at preserving life, leaves $\mathrm{RC}$ walls vulnerable to damage during strong seismic excitations. This damage was observed following many earthquakes including the 1985 Mexico earthquake [4], the 1999 Chi-Chi earthquake [5], the 2010 Maule earthquake [6], and the 2011 Christchurch earthquake [7].

Residual drift is one of the measures to evaluate the seismic performance of a structure. FEMA P-58-1 [8] introduced four damage states related to residual drift ratios. The limit for repairable structural elements was set at $1 \%$ residual inter-story drift [8]. McCormick et al. [9] concluded that the economical limit is $0.5 \%$. To mitigate the residual displacements of RC walls, self-centering methods that rely on unbounded post-tensioned tendons and supplementary energy dissipation devices were proposed $[10,11,12]$. Although these methods have resulted in improved seismic performance, researchers are still exploring new techniques.

Superelastic shape memory alloy (SE-SMA) can recover its inelastic deformations upon the removal of the applied load. This unique property has been utilized by many researchers $[13,14,15,16,17$, 18]. The flag-shaped hysteresis of SE-SMA can eliminate the seismic residual drifts on the cost of lower energy dissipation as compared to steel reinforcement. Also, the lower modulus of elasticity of SE-SMA bars leads to higher seismic deformations. Researchers have addressed these disadvantages by minimizing the amount of SE-SMA material $[17,18]$. The potential use of SE-SMA bars was extended to RC walls by a number of researchers. Effendy et al. [19] used external diagonal SE-SMA 
bars to upgrade the seismic performance of existing squat walls. Test results showed a significant reduction in the residual displacements combined with a $16 \%$ to $26 \%$ increase in the peak shear strength. Abdulridha [20] experimentally studied the cyclic behaviour of a concrete wall. The boundary elements were reinforced with longitudinal SE-SMA bars at the plastic hinge region [20]. The SE-SMA bars increased the wall ductility and significantly reduced the residual displacements. Abraik and Youssef [21] conducted an analytical study to identify the performance of SE-SMA RC squat and intermediate walls considering different SE-SMA bar locations. The results highlighted that location of the SE-SMA bars have a significant effect on the wall seismic performance.

Research addressing the seismic vulnerability of tall concrete walls reinforced with SE-SMA bars is missing in the literature. The paper addresses this topic. It starts by identifying the plastic hinges for 10 and 20-story steel RC walls that are designed and detailed per CSA A23.3 [22] and NBCC [23].

The influence of using SE-SMA bars is then evaluated. Fragility curves are presented considering various damage states.

\section{NUMERICAL MODEL}

A multi-story RC wall is shown in Figure 1a. The walls are modeled using the Shear-Flexural Interaction Multi-Vertical Line Element Model (SFI-MVLEM), Figure 1b. This model was implemented in the Open System for Earthquake Engineering Simulation software (OpenSees) [24] by Kolozvari [25]. It allows simulating the seismic response of RC walls using two-dimensional membrane panels. The edge and interior panels represent the boundary elements and the wall web, respectively. The panels are modeled using a fixed angle crack approach. The rigid beams at the top and bottom enforces a plane section assumption. The flexural response of a wall is captured through 
the axial deformations of the $\mathrm{RC}$ panels in the vertical direction. The average normal vertical strain is determined by dividing the average vertical deformation by the element height $h$. The relative rotation between the top and bottom of the wall element is assumed to happen at a height $c h$, measured from the bottom face. The value of the height coefficient $c$ was recommended to be taken as 0.4 by Orakcal and Wallace [26]. The shear deformation of the SFI-MVLEM element is determined by transferring the external deformation components to a point at a height $c h$. The shear strain for each panel is calculated by dividing the shear deformation by the element height $h$. The normal strain in the horizontal direction is obtained by dividing the horizontal deformation at the internal degrees of freedom by the panel width. The effect of increasing or decreasing the number of RC panels or the number of SFI-MVLEM on the total displacement was found to be insignificant [25].

The built-in nonlinear material constitutive relationship, proposed by Menegotto and Pinto [27], was used to model the steel reinforcing bars (Figure 2a). The concrete was modeled using the constitutive relationships proposed by Chang and Mander [28], shown in Figure 2b. It should be noted that the origin of the tension envelope curve depends on the unloading strain [25]. Figure 2c illustrates the symmetric SE-SMA self-centering model. The SE-SMA model parameters were evaluated experimentally by Tazarv and Saiidi [14] and Varela and Saiidi [29]. The modulus of elasticity of the SE-SMA bars $\left(E_{S M A}\right)$, the stress at which inelastic deformations initiate $\left(f_{S M A}\right)$, and the post-yield strength $\left(K_{2}\right)$ are assumed to be $38,000 \mathrm{MPa}, 380 \mathrm{MPa}$, and $1725 \mathrm{MPa}$, respectively. The ultimate strain for SE-SMA is assumed to correspond to the point at which it loses the ability to recover its original shape (strain of $7 \%$ ). 
Local failure is defined when the strain in the longitudinal steel reinforcement reaches the yield strain $\varepsilon_{y}$ and the concrete compressive strain reaches $0.2 \%[32,33]$. The structural and non-structural elements are expected to have sustained significant damage at this stage [32].

An experimental shake table test of a slender eight-story concrete wall, tested by Ghorbanirenani et al. [30], was selected to further validate the SFI-MVLEM model. The wall, shown in Figure 3a, was designed per NBCC 2005 [31] with a force reduction factor of 2.8 .

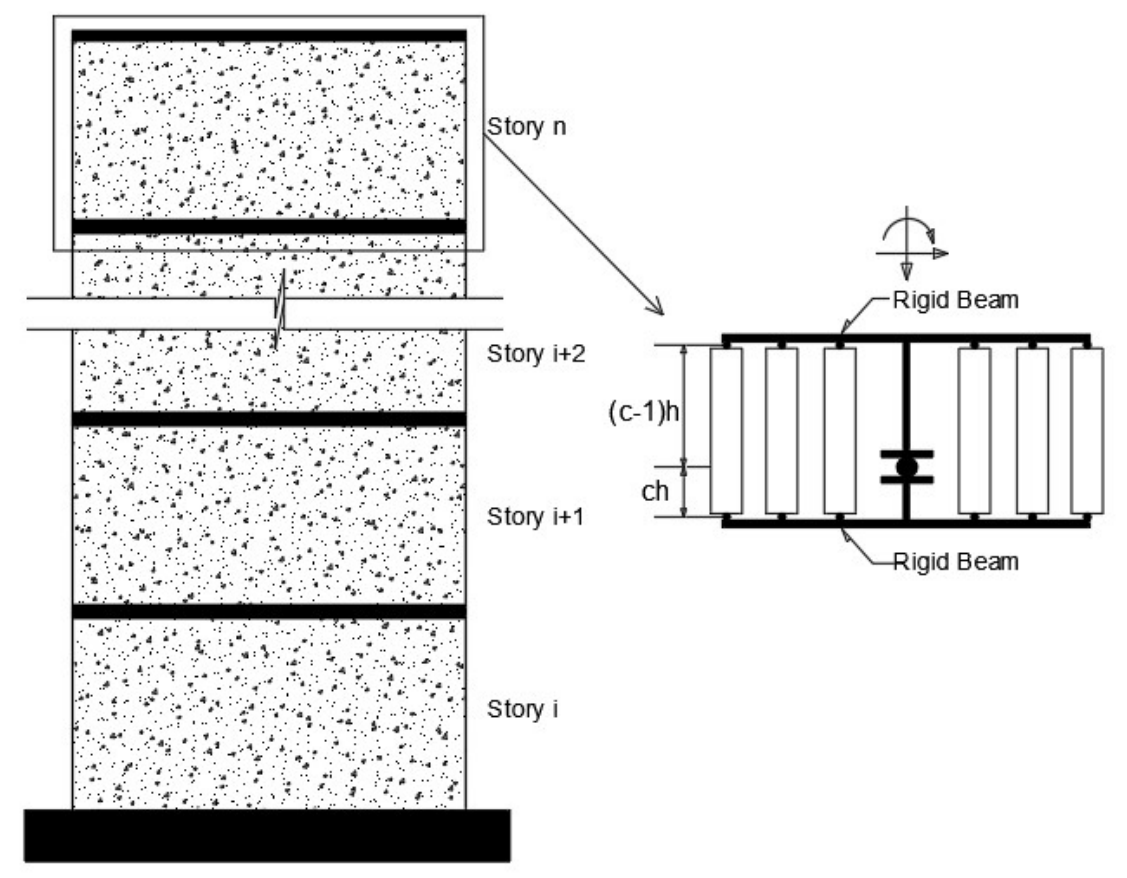

(a)

(b)

Figure 1. MVLE model (a) RC wall; (b) One-story model 


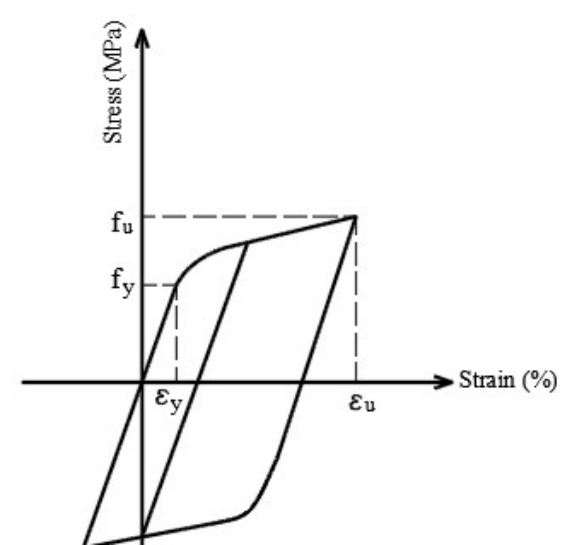

(a)

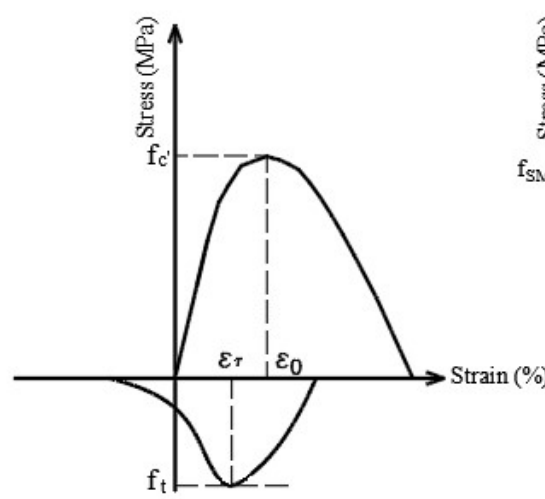

(b)

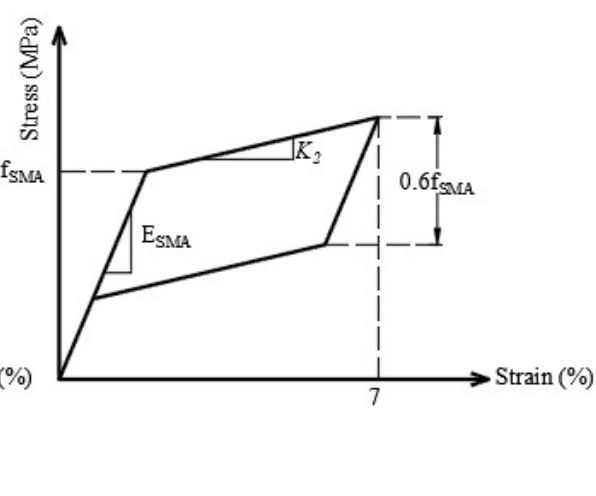

(c)

Figure 2. Materials model (a) steel bars; (b) concrete; (c) SE-SMA

A simulated time history ground motion developed for eastern North America was used to experimentally test the wall. Inelastic flexural response was developed at the wall base and at the sixth story. Flexural-shear cracks at the wall base and flexural cracks at the sixth level were also observed. The wall was modeled using eight SFI-MVLEM elements. The predicted results matched closely the experimental ones, as shown in Figure 4a. Slight discrepancies between the numerical predictions and experimental data at 7 seconds can be observed.

Abdulridha [20] performed a large-scale test on an SE-SMA RC wall to evaluate its performance when subjected to lateral loading as shown in Figure $3 \mathrm{~b}$. The experimental load-displacement response, shown in Figure 4b, is compared with predictions of Finite Element Analysis (FEA) by Abdulridha [20] and SFI-MVLEM model. The initial stiffness predicted by the FEA and Opensees are similar and higher than the experimental results by about $12 \%$. This discrepancy is related to the bond slip effect, which is not modeled. The yield displacement form both models is $8 \%$ higher than the experimental value. The SFI-MVEL model predicted accurately the ultimate strength at a 
displacement of $73 \mathrm{~mm}$, whereas the ultimate strength predicted by the FEA model was higher by about $3 \%$.
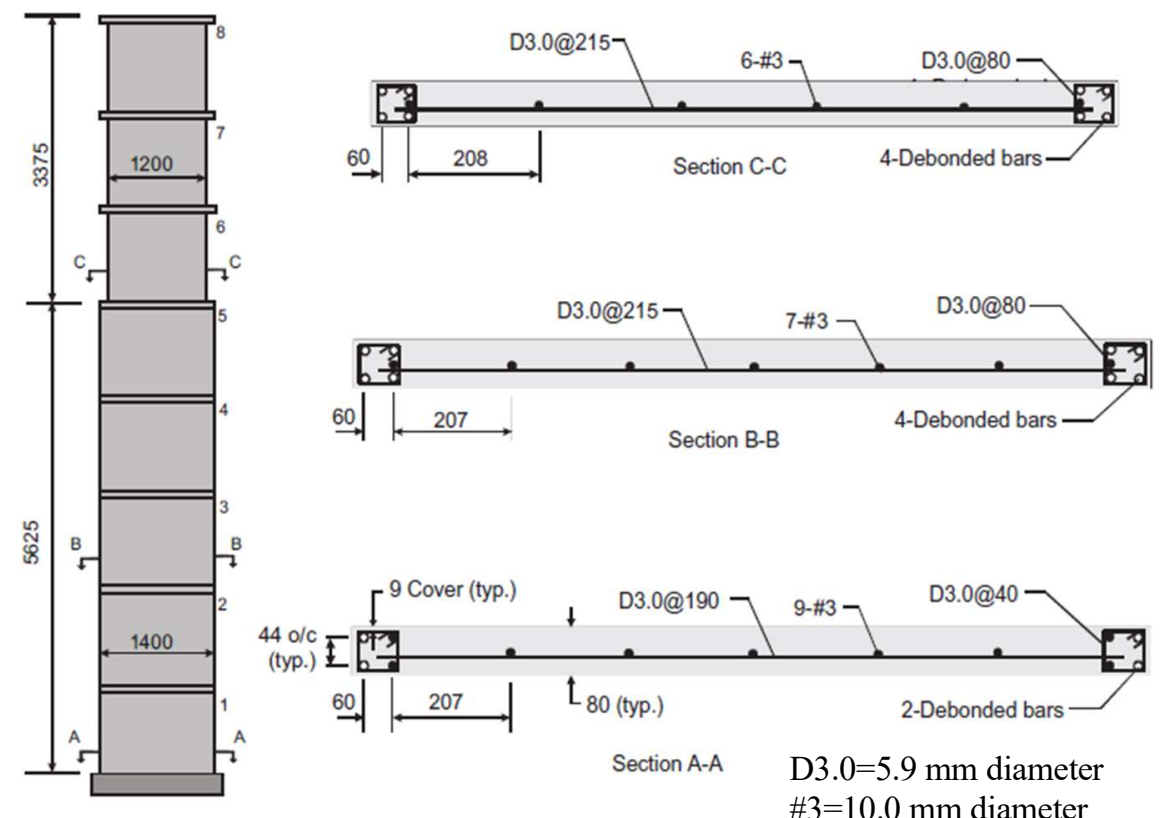


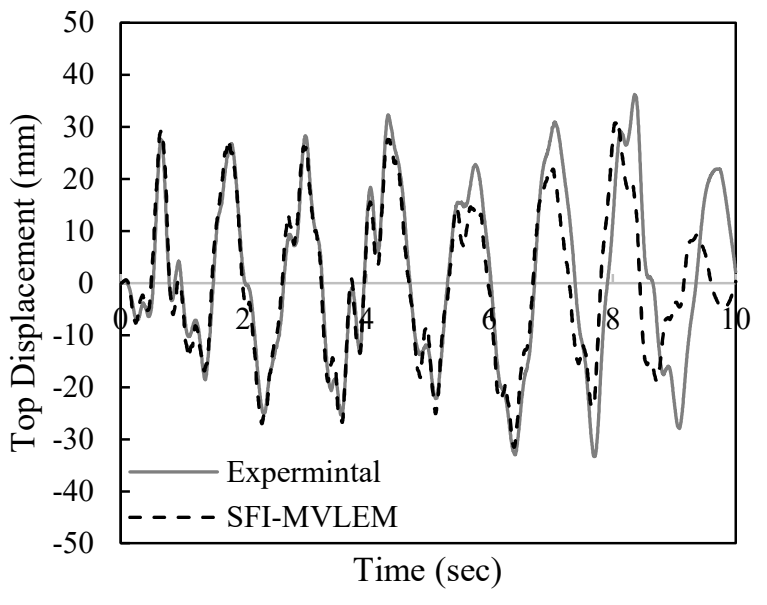

(a)

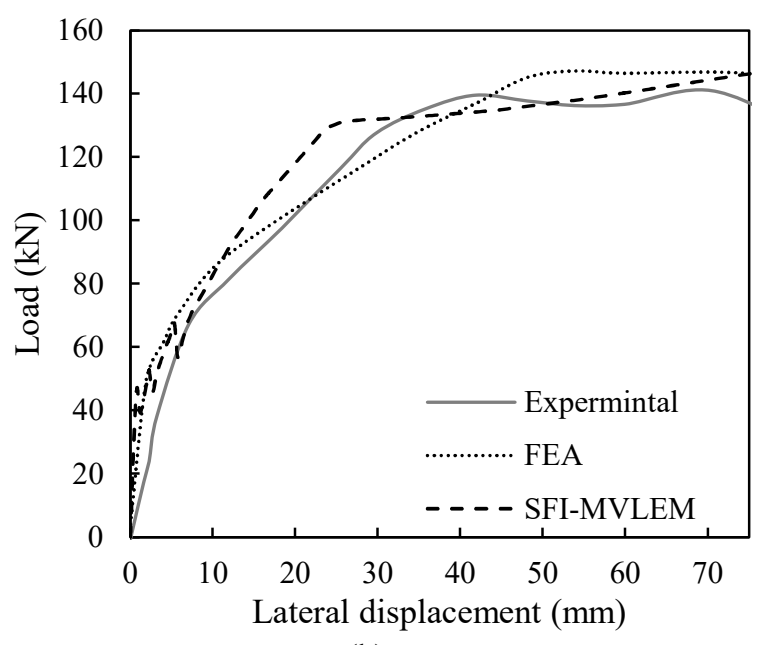

(b)

Figure 4. Numerical model versus the experimental data: (a) Steel RC wall tested by Ghorbanirenani [30]; (b) SE-SMA RC wall tested by Abdulridha [20]

\section{STEEL RC WALLS}

The structural plan of the considered RC building is shown in Figure 5. The building is assumed to be in southern British Columbia. The concrete shear walls are designed and detailed using CSA A23.3 [22] and NBCC [23]. The overstrength $\left(R_{0}\right)$ and ductility $\left(R_{d}\right)$ factors are 1.6 and 3.5 , respectively. The concrete compressive strength and the yield strength of the steel rebars are assumed to be $30 \mathrm{MPa}$ and $450 \mathrm{MPa}$, respectively. The structural lumped mass includes the self-weight and $25 \%$ of the floor live load, assumed $2.8 \mathrm{kN} / \mathrm{m}^{2}$. Characteristics of the considered walls, shown in Figure $5 \mathrm{c}$, are summarized in Table 1. 
Table 1. Characteristics of considered walls

\begin{tabular}{l|c|c}
\hline & 10 -story & 20-story \\
\hline Wall thickness $\left(b_{w}\right)$ & $250 \mathrm{~mm}$ & $350 \mathrm{~mm}$ \\
Wall length $\left(l_{w}\right)$ & $4060 \mathrm{~mm}$ & $6000 \mathrm{~mm}$ \\
Length of wall boundary element $\left(l_{b l}\right)$ & $500 \mathrm{~mm}$ & $600 \mathrm{~mm}$ \\
Floor height & $2800 \mathrm{~mm}$ \\
Axial load per story & \multicolumn{2}{|c}{$233 \mathrm{kN}$} \\
Weight per story & \multicolumn{2}{|c}{$0.25 \%$} \\
Vertical and horizontal steel ratio in the web $\left(\rho_{v w}, \rho_{h w}\right)$ & \multicolumn{2}{|c}{$0.67 \%$} \\
Horizontal steel ratio in the boundary elements $\left(\rho_{h b}\right)$ & \multicolumn{2}{|c}{$0.5 \%$} \\
Vertical and horizontal steel ratio in the web at plastic hinge $\left(\rho_{v w}, \rho_{h w}\right)$ & $1.28 \%$ & $1.90 \%$ \\
Vertical steel ratio in the boundary elements $\left(\rho_{v b}\right)$ & 0.1 & 0.12 \\
Maximum axial load ratio $\left(\frac{P}{A_{g} f_{c}^{\prime}}\right)$ & \\
\hline
\end{tabular}

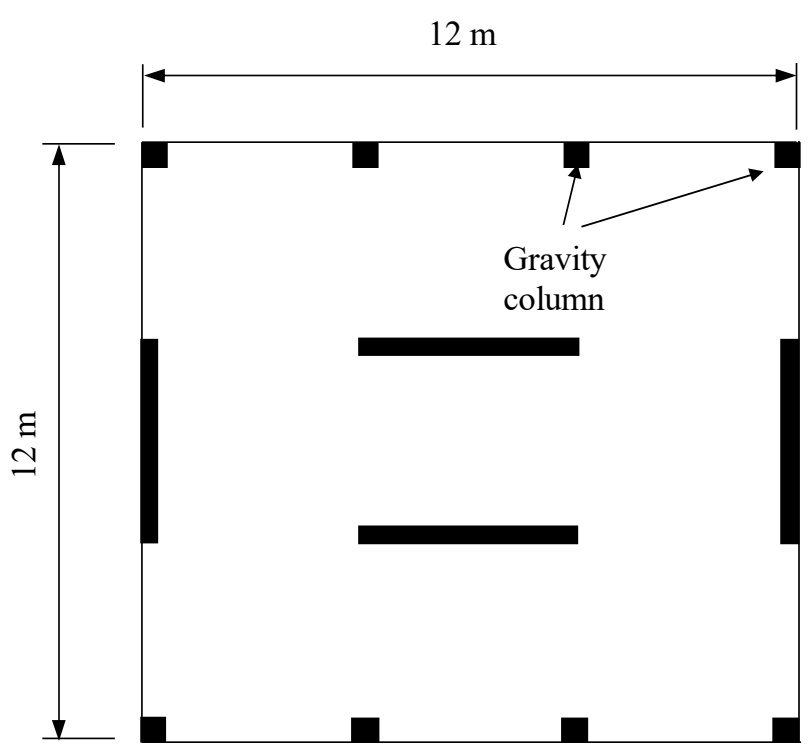

(a)

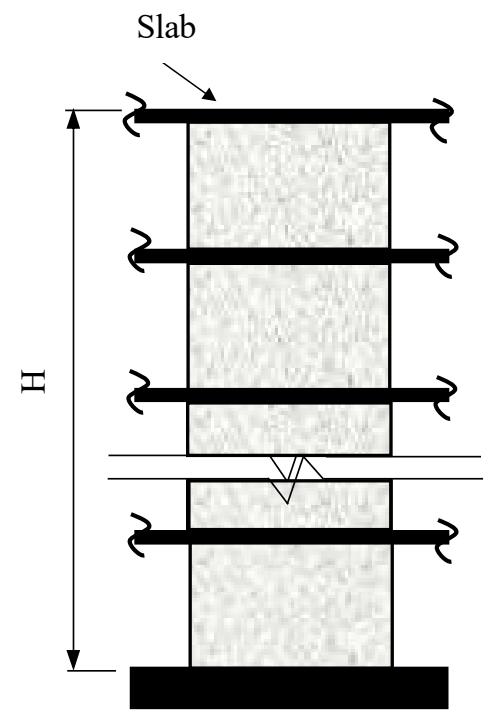

(b)

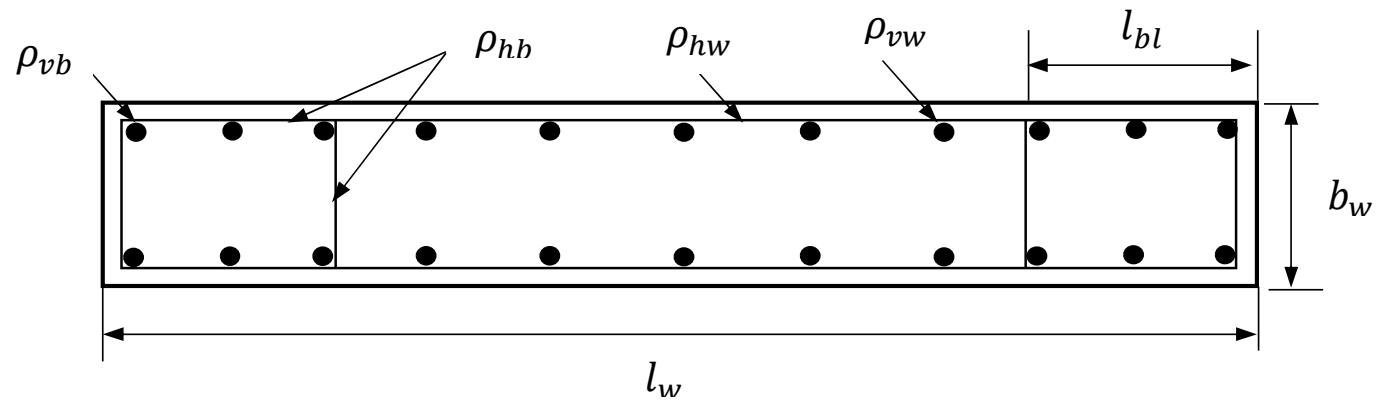

(c)

Figure 5. Considered building (a) structural plan; (b) wall elevation; (c) typical wall section 
Steel RC walls are designed based on A23.3 [22], which assumes that the plastic hinge develops at the wall base. Detailing requirements of A23.3 [22] ensure a certain level of ductility along the wall height by modifying the factored moment $M_{f}$, as shown in Figure 6 . The static analysis procedure of A23.3 [22] assumes a linear variation of the factored moment starting at the top of the plastic hinge as shown in Figure 6. Although CSA ensures adequate level of ductility to mitigate yielding at any point outside the plastic hinge zone, there is a possibility for spread of plasticity along the wall height $[30,32,33,34]$. The design shear forces found from the analysis are to be increased over the wall height by the ratio between the moment of resistance $M_{r}$ and the factored moment $M_{f}$. The corresponding shear values must exceed the smaller of the shear corresponding to the probable moment capacity and the shear demand calculated assuming $R_{d} R_{0}$ equal to 1.3 .

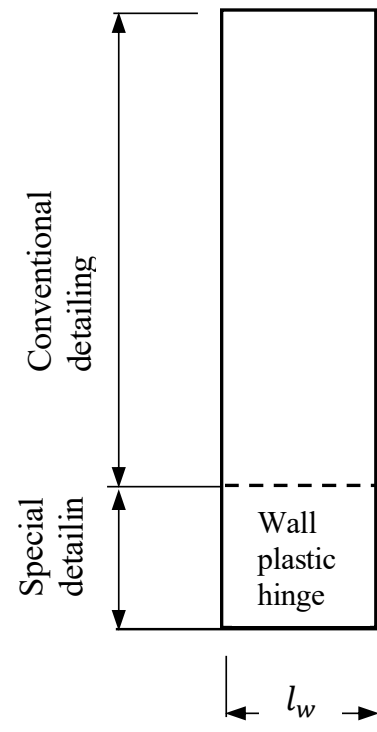

(a)

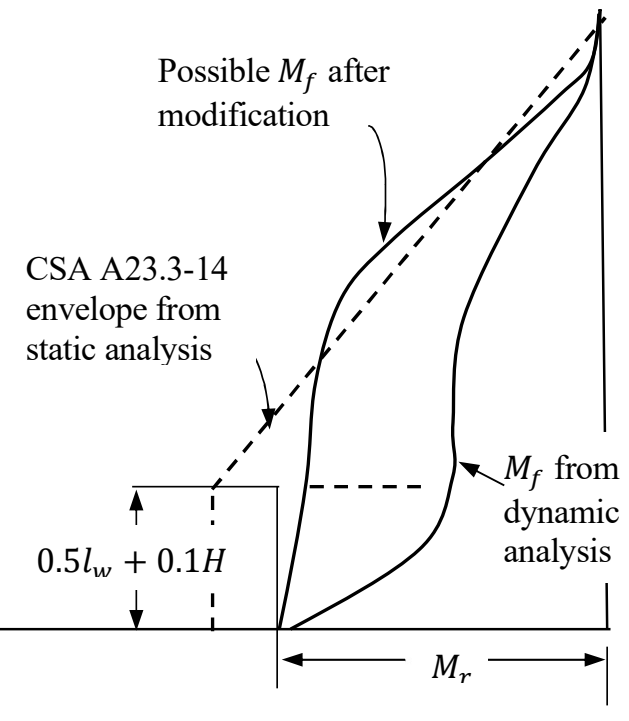

(b)

Figure 6. Capacity design moment envelopes for steel RC wall: (a) detailing requirements; (b) variation of moments along wall height 


\section{SEISMIC GROUND MOTIONS}

The Conditional Mean Spectrum (CMS) proposed by Baker [35] was utilized to select the ground motions. The method is based on choosing the spectrum that has a target amplitude for a specific structure period. An eigenvalue analysis was used to determine the structure period for the steel RC walls. The resulting periods were $1.67 \mathrm{~s}$ and $3.06 \mathrm{~s}$ for the 10 and 20 -story walls, respectively. Seven level of hazards with return periods ranging from 72 years to 2475 years were selected, as shown in Table 2. Soil class D with shear wave velocity ranging from 180 to $360 \mathrm{~m} / \mathrm{s}$ was assumed. Each of the hazard levels is represented by 20 ground motions having the spectral accelerations shown in Table 2.

Table 2. Hazard levels considered for Southern British Columbia

\begin{tabular}{c|c|c|c}
\hline Hazard Level & Return Period (years) & $S_{a 10}\left(T_{1}=1.67\right)(g)$ & $S_{a 20}\left(T_{1}=3.06\right)(g)$ \\
\hline 1 & $72[50 \%$ in 50] & 0.06 & 0.05 \\
2 & $224[20 \%$ in 50] & 0.17 & 0.09 \\
3 & $336[20 \%$ in 75$]$ & 0.21 & 0.12 \\
4 & $475[10 \%$ in 50] & 0.25 & 0.15 \\
5 & $975[5 \%$ in 50] & 0.34 & 0.19 \\
6 & $1462[5 \%$ in 75$]$ & 0.40 & 0.26 \\
7 & $2475[2 \%$ in 50] & 0.46 & 0.30 \\
\hline
\end{tabular}

\section{SE-SMA RC WALLS}

Multi Strip Analysis (MSA) was used to evaluate the seismic response of the 10 and 20-story steel $\mathrm{RC}$ walls. Strain profiles along the wall heights were used to determine the length and locations of the SE-SMA bars. Figure $7 \mathrm{~b}$ shows the mean strains in the longitudinal bars of the 10 and 20 story steel RC walls, when subjected to 20 earthquakes with 2475 years return period. The main plastic hinge is formed at the base. However, an additional plastic hinge is formed at mid-height of the wall. The steel strain at the $5^{\text {th }}$ and $6^{\text {th }}$ stories of the 10 -story steel $\mathrm{RC}$ wall exceeded the yield strain. The 
same trend is observed for the 20 -story wall, where the strain in the rebars at $10^{\text {th }}, 11^{\text {th }}, 12^{\text {th }}$, and $13^{\text {th }}$ stories exceeded the yield strain. In both buildings, plastic hinge length is about $20 \%$ of the total wall height.

The design of the SE-SMA RC is taken similar to the steel RC wall. SE-SMA bars are assumed to replace the vertical steel bars at the boundary elements for the plastic hinge length. The SE-SMA bars are connected to steel bars using mechanical couplers as proposed by Youssef et al. [15]. Resulting periods for SE-SMA RC walls were $1.71 \mathrm{~s}$ and $3.1 \mathrm{~s}$ for the 10 and 20-story buildings, respectively.

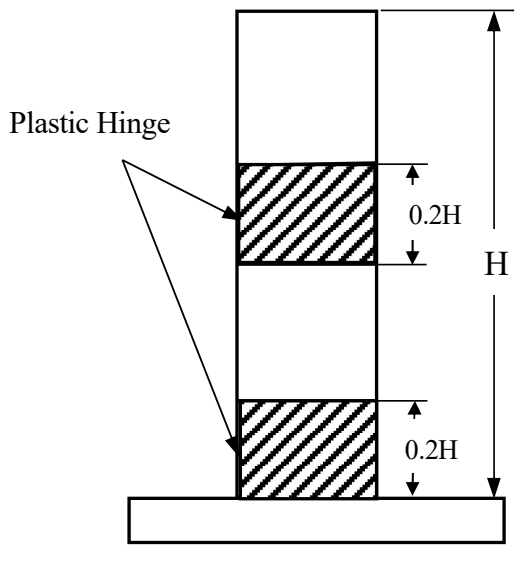

(a)

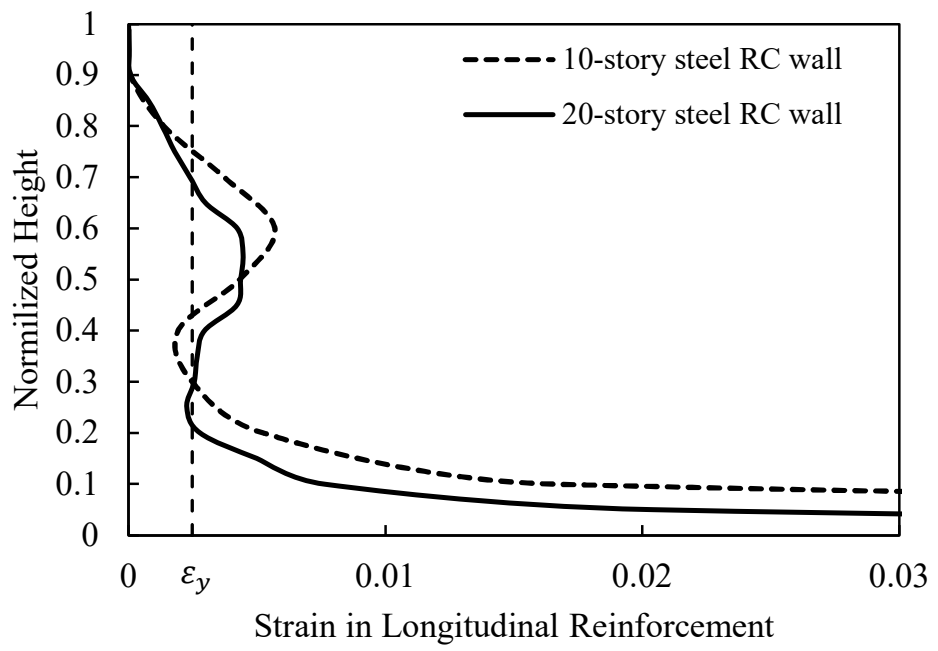

(b)

Figure 7. Plastic hinges in the considered walls: (a) location of plastic hinges; (b) strain profile along the wall height

\section{SEISMIC PERFORMANCE OF STEEL AND SE-SMA RC WALLS}

Figures 8 and 9 compare the shear forces and bending moments for the steel and SE-SMA RC walls at the first and second periods. The shear forces for the steel RC walls were higher than the SE-SMA walls by about $5 \%$ to $10 \%$. Similar trend is noticed for the bending moments, which were higher by about $8 \%$ to $12 \%$ at the wall base and $3 \%$ to $15 \%$ at mid-height. The flexibility of the SE-SMA rebar slightly lengthened the wall natural period, which resulted in a decrease in the bending moments and shear forces. 


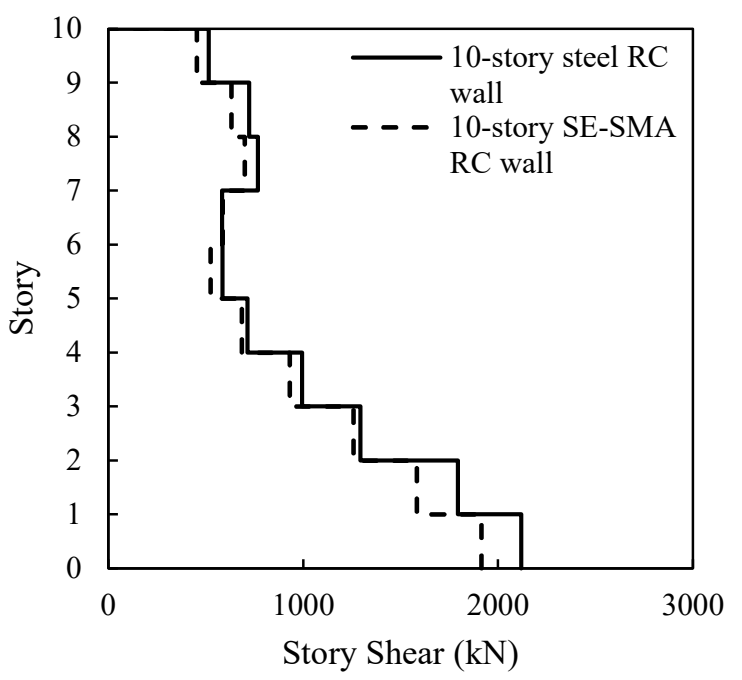

(a)

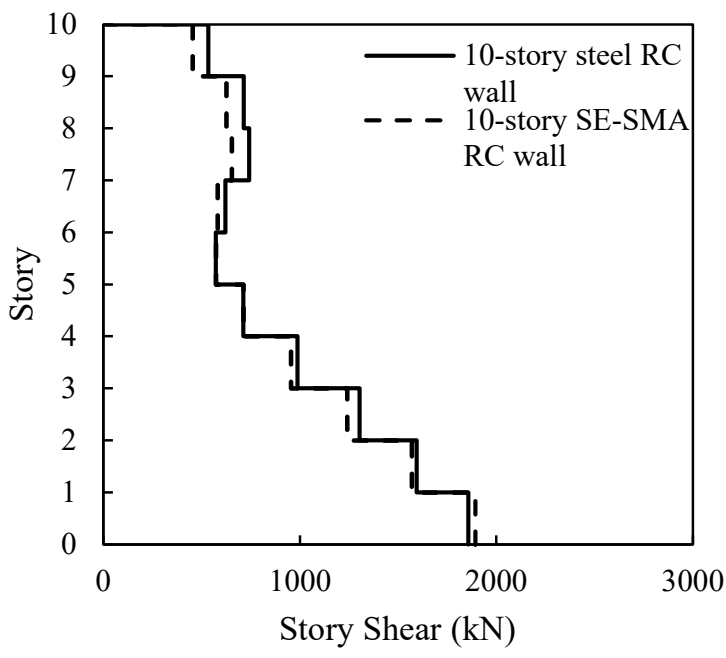

(c)

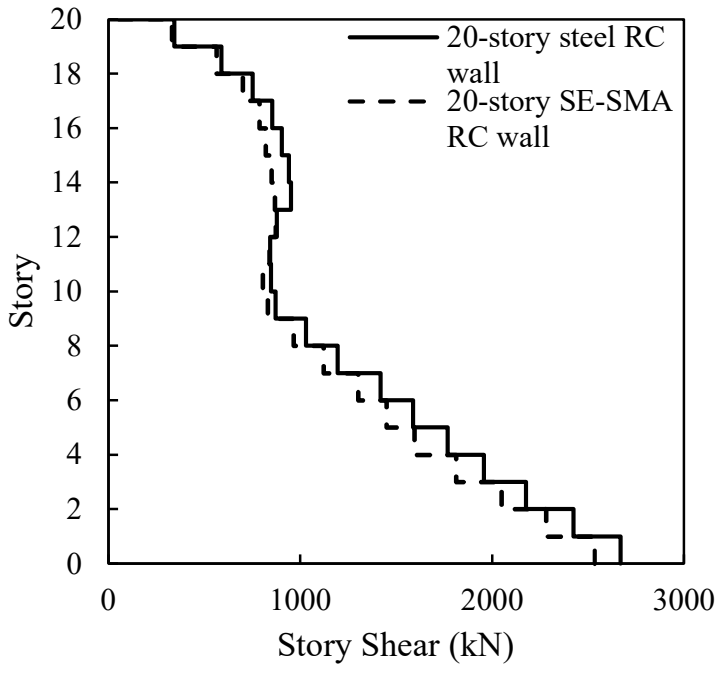

(b)

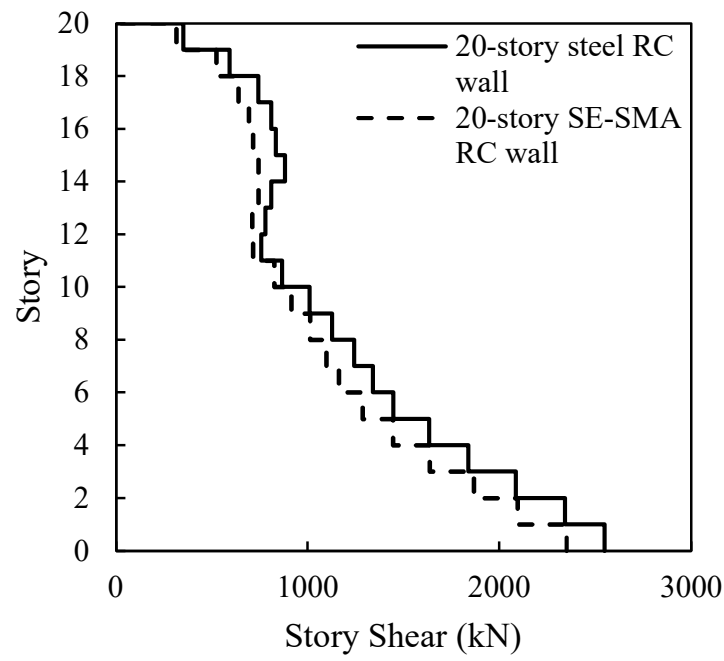

(d)

Figure 8. Shear force along wall height at: (a) 10-story first period; (b) 20-story first period; (c) 10-story second period; (d) 20-story second period 


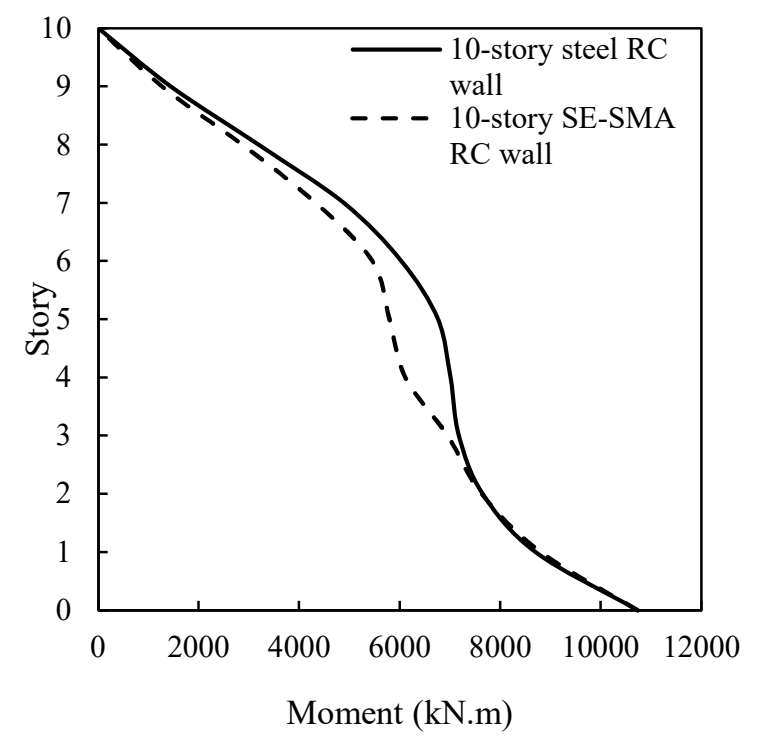

(a)

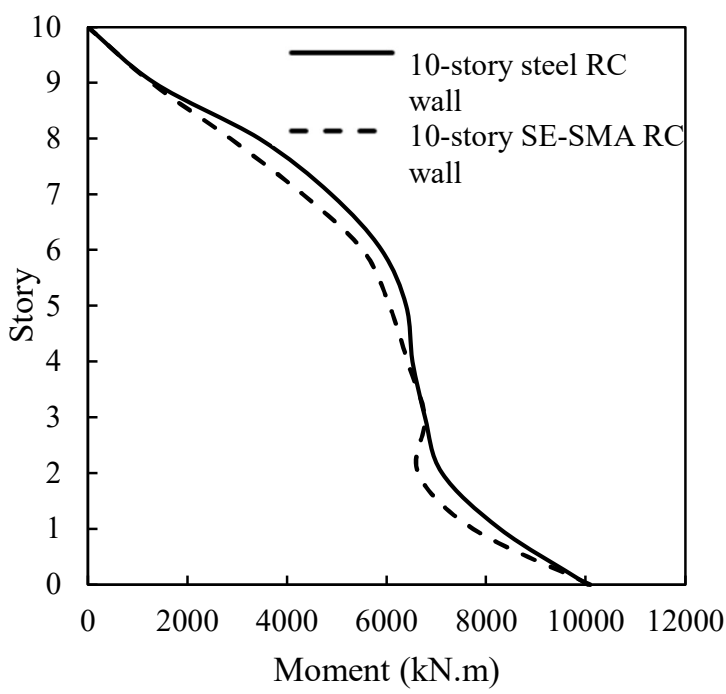

(c)

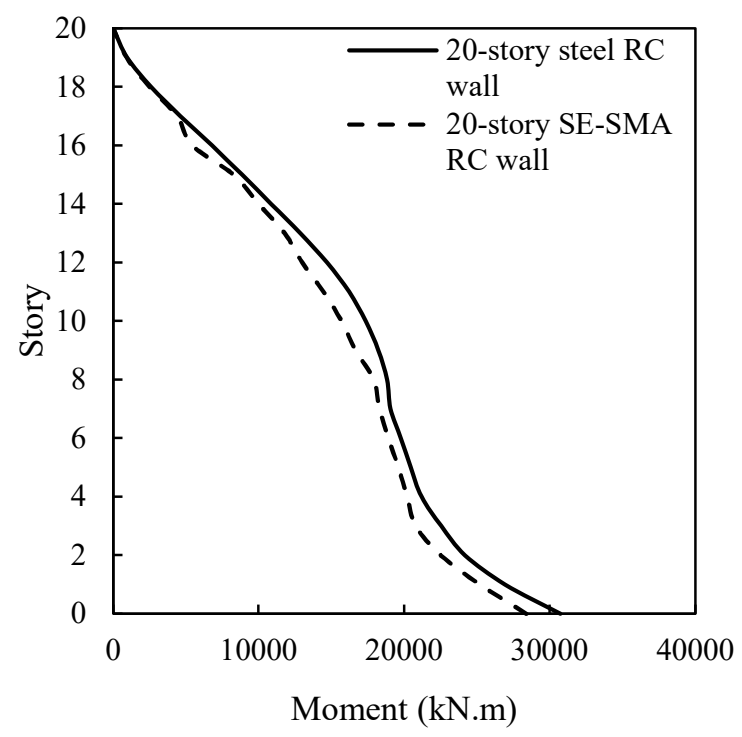

(b)

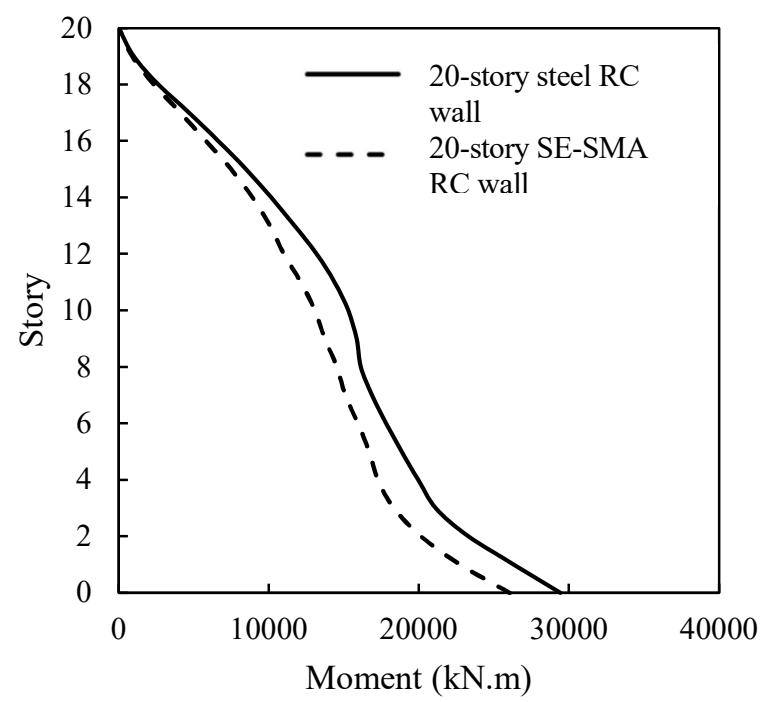

(d)

Figure 9. Bending moment along wall height at: (a) 10-story first period; (b) 20-story first period; (c) 10-story second period; (d) 20-story second period 
The lateral displacement envelopes are plotted in Fig. 10 for 2475-, 475-, and 72-year events. The displacements of the considered walls follow approximately a linear trend. The lateral displacement of the SE-SMA RC walls are higher than the steel RC walls by 6 to $16 \%$. This increase is due to the lower stiffness of the SE-SMA bars.

The residual displacement envelopes are plotted in Figure 11. For low intensity seismic ground motions, the residual displacements of the SE-SMA RC walls are not significantly different from the steel RC walls as the behaviour was in the elastic range. The use of SE-SMA bars reduces the residual displacements by $19 \%$ to $50 \%$ for moderate and high level seismic ground intensities. The reduction was more pronounced for the 10 -story wall, which is less flexible as compared to the 20 -story wall. Lateral displacements and residual displacements envelopes for different ground motion intensity levels are summarized in Table 3. 


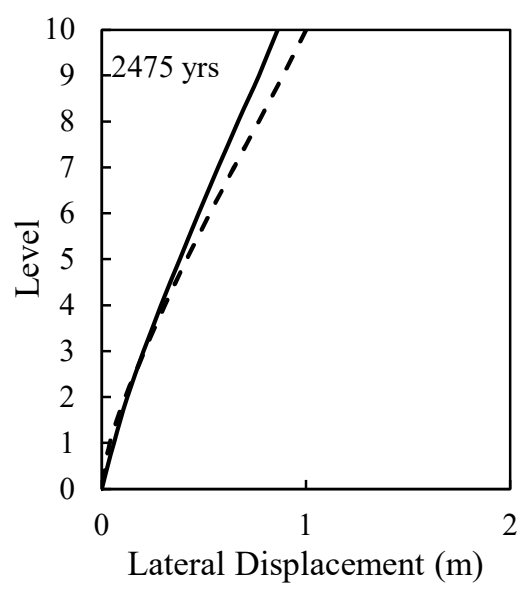

(a)

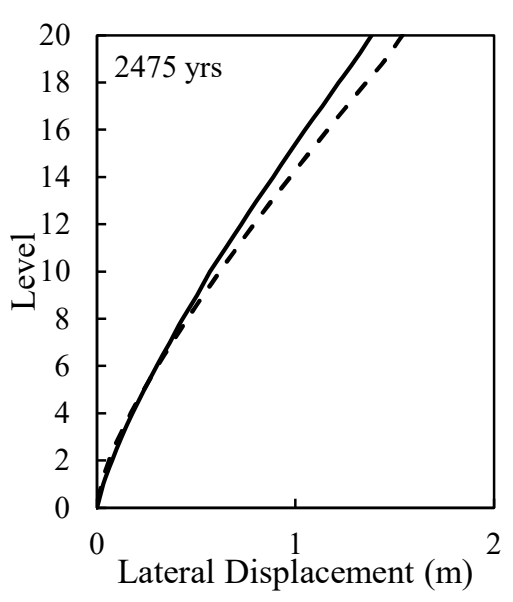

(d)

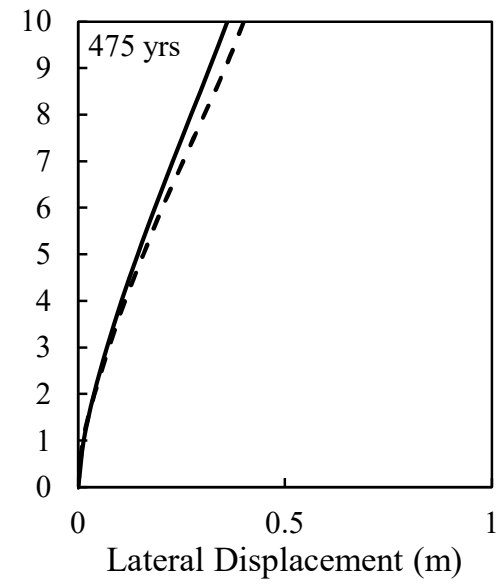

(b)

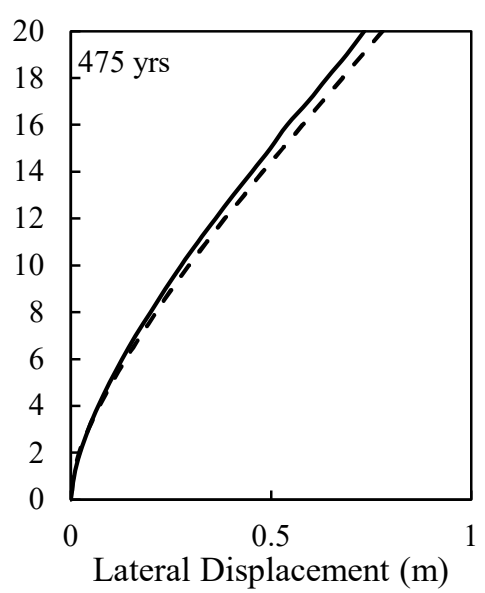

(e)

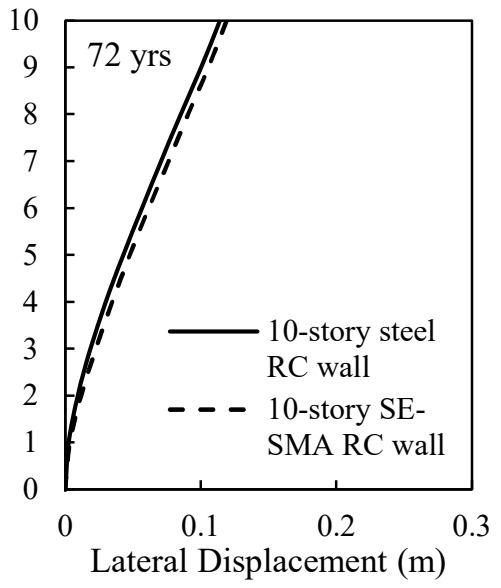

(c)

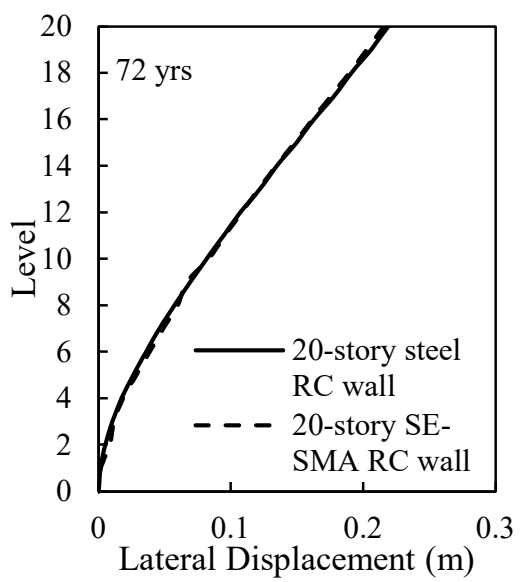

(f)

Figure 10. Lateral displacement envelopes for: (a) Return period 2475 yrs/ 10-story wall; (b) Return period 475 yrs/ 10-story wall; (c) Return period 72 yrs/ 10-story wall; (d) Return period 2475 yrs/ 20-story wall; (e) Return period $475 \mathrm{yrs} / 20$-story wall; (f) Return period 72 yrs/ 20 -story wall 


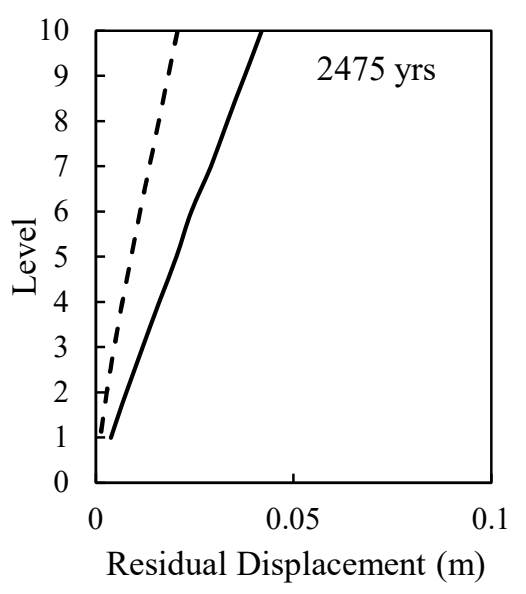

(a)

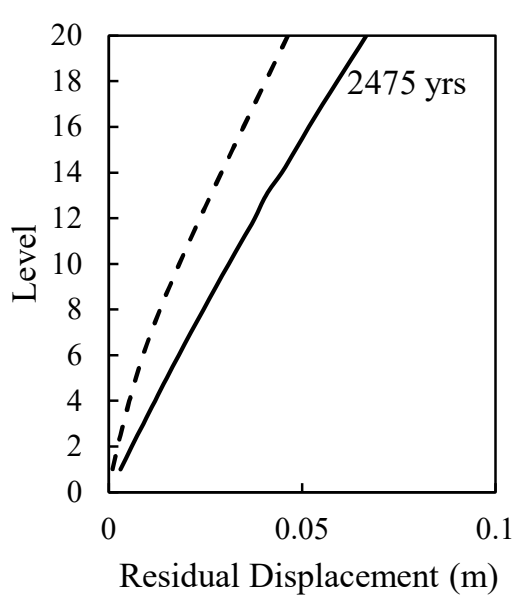

(d)

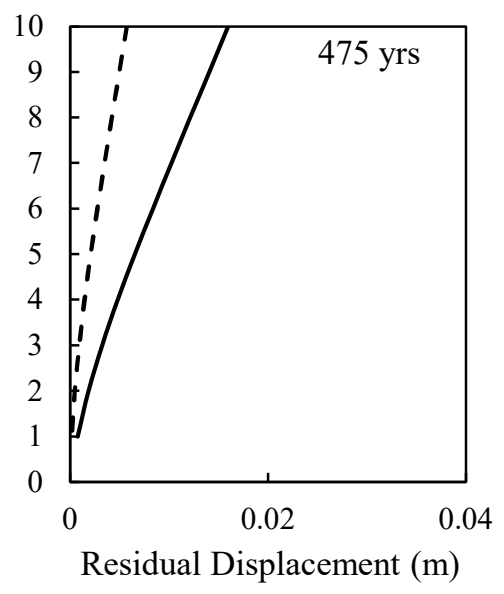

(b)

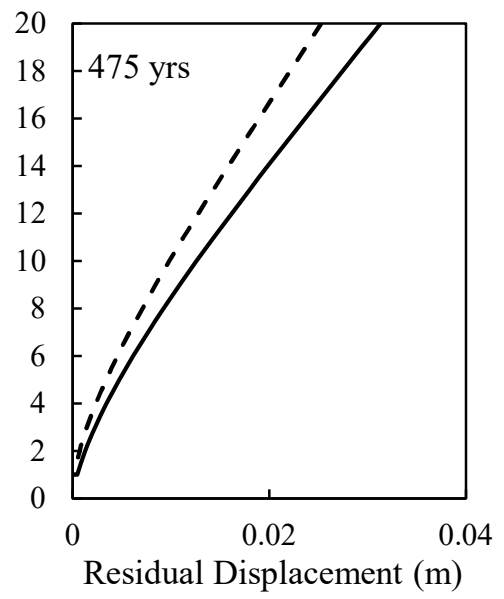

(e)

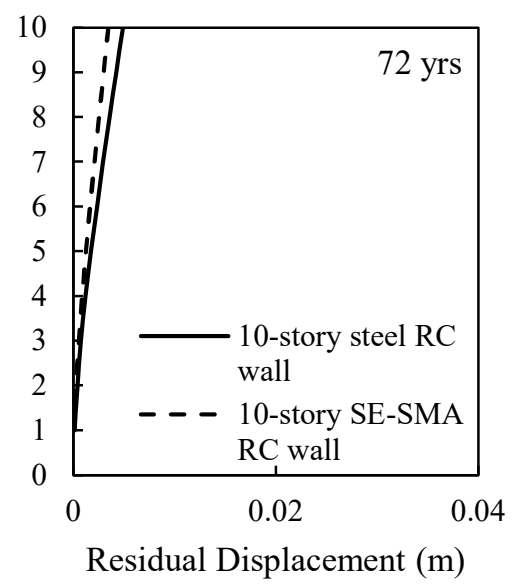

(c)

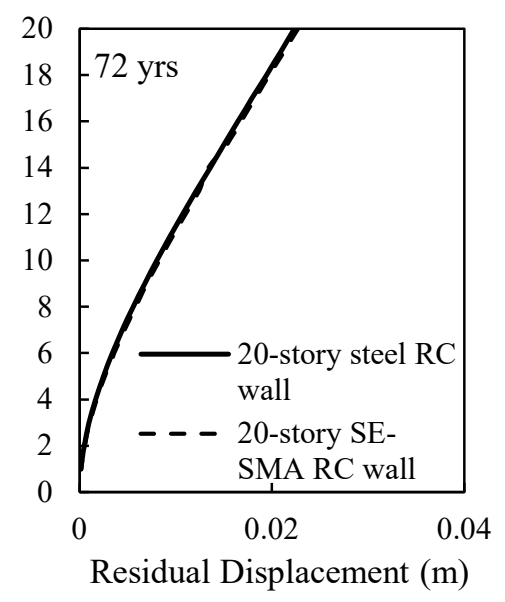

(f)

Figure 11. Residual displacement envelopes for: (a) Return period 2475 yrs/ 10-story wall; (b) Return period 475 yrs/ 10-story wall; (c) Return period 72 yrs/ 10-story wall; (d) Return period 2475 yrs/ 20-story wall; (e) Return period 475 yrs/ 20-story wall; (f) Return period 72 yrs/20-story wall 
Table 3. Peak lateral displacements and residual displacements

\begin{tabular}{|c|c|c|c|c|c|c|c|c|}
\hline \multirow[t]{3}{*}{ Events } & \multicolumn{4}{|c|}{10 -story wall } & \multicolumn{4}{|c|}{20 -story wall } \\
\hline & Steel & SE-SMA & Steel & SE-SMA & Steel & SE-SMA & Steel & SE-SMA \\
\hline & \multicolumn{2}{|c|}{ Lateral Displacement (m) } & \multicolumn{2}{|c|}{$\begin{array}{c}\text { Residual } \\
\text { Displacement (m) }\end{array}$} & \multicolumn{2}{|c|}{ Lateral Displacement (m) } & \multicolumn{2}{|c|}{$\begin{array}{c}\text { Residual Displacement } \\
\text { (m) }\end{array}$} \\
\hline 2475 & 0.86 & 1.00 & 0.042 & 0.020 & 1.30 & 1.54 & 0.06 & 0.040 \\
\hline 475 & 0.36 & 0.40 & 0.016 & 0.005 & 0.73 & 0.77 & 0.05 & 0.03 \\
\hline 72 & 0.11 & 0.12 & 0.005 & 0.003 & 0.21 & 0.21 & 0.02 & 0.02 \\
\hline
\end{tabular}

\section{FRAGILITY FUNCTION}

Seismic damage can be assessed using story drift ratio [36] or inter-story drifts [37]. The damage level for steel RC walls and SE-SMA RC walls can be judged as similar based on the story drifts (Figure 10) or significantly different based on the residual drifts (Figure 11). In this section, fragility curves are presented for both inter-story and residual drifts.

A fragility function describes the probability of damage for a given seismic intensity (IM). It can be expressed using Equation 1 [38]:

$$
P(C \backslash I M=x)=\Phi\left[\frac{\ln \left(\frac{x}{\theta}\right)}{\beta}\right]
$$

Where, $P$ is the probability of exceeding a specific damage level $C, \Phi$ is the standard normal cumulative distribution, $\theta$ is the median of the fragility function, and $\beta$ is the standard deviation of $\ln (I M)$. The fragility curve can be obtained using incremental dynamic analysis [39]. In this 
approach, the seismic intensity is incrementally increased until collapse. However, this method is time-consuming and raises the concern of whether scaling moderate intensity ground motions can represent high intensity ground motions [38, 40]. Multi-Strip Dynamic Analysis (MSA) is an efficient approach that addresses this concern [38]. In this approach, the structure is subjected to a number of ground motions representing each hazard level.

\subsection{FRAGILITY CURVES}

The mean roof inter-story drifts (ID) and the residual roof drifts (RD) for seven seismic hazard levels, representing return periods of 72 years to 2475 years, are summarized in Table 4 . Figure 12 displays the MSA curves that depict the relationship of the mean roof inter-story drift against the seven hazard intensity levels. The mean roof inter-story drift for the 10-story SE-SMA wall is 19\% higher than that of the steel RC wall. The 20 -story walls have similar behaviour up to a hazard intensity of $0.2 \mathrm{~g}$. At higher intensity levels, the 10-story SE-SMA RC wall experiences slightly higher inter-story drifts compared to the 20-story SE-SMA RC wall. This apparent difference in the inter-story drift is due to differences in the wall heights and boundary element reinforcement ratios.

Figure 13 shows the relationship between the residual roof displacement and the ground motion intensity level. The residual displacements for the 10 and 20-story steel RC walls are higher than the corresponding SE-SMA RC walls. 


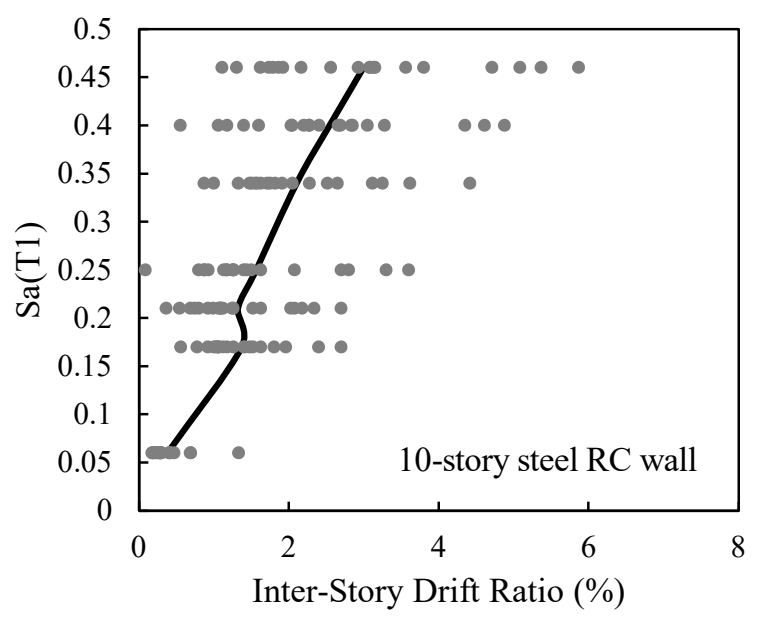

(a)

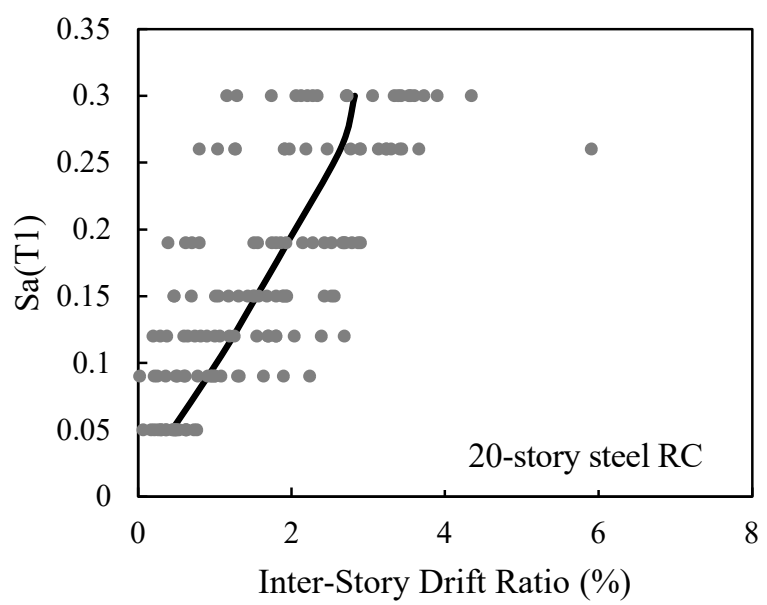

(c)

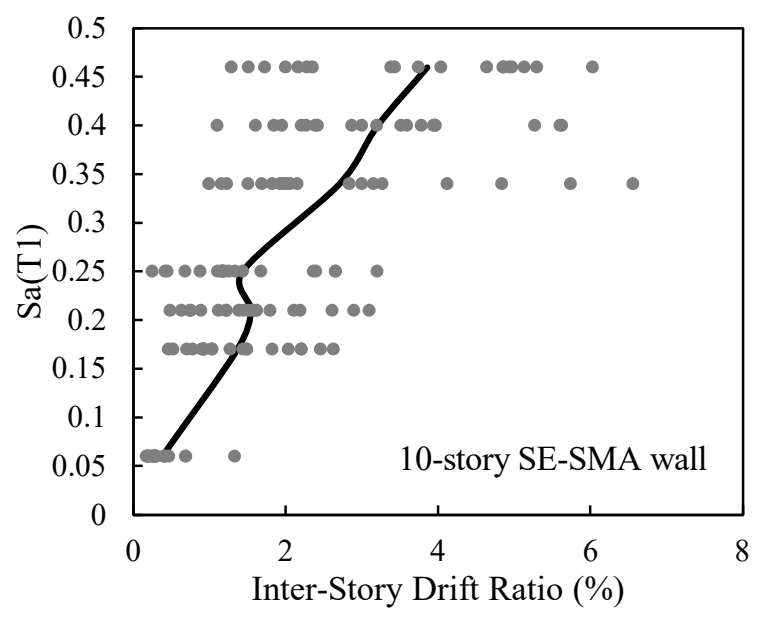

(b)

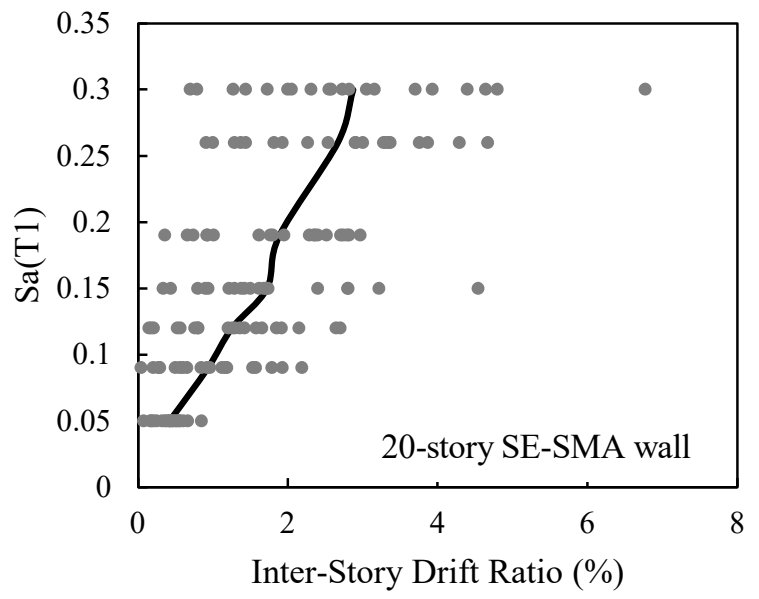

(d)

Figure 12. Maximum inter-story drift ratios as function of ground motion intensity, for (a) 10-story steel RC wall; (b) 10story SE-SMA RC wall; (c) 20-story steel RC wall; (d) 20-story SE-SMA RC wall 


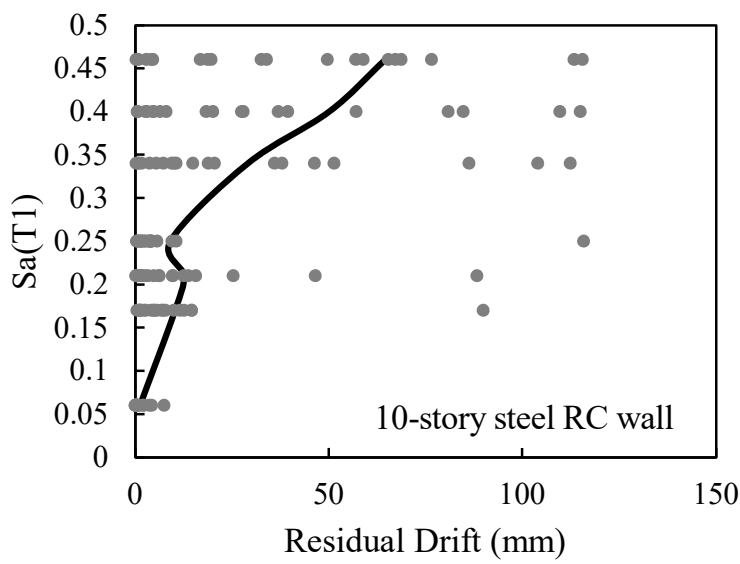

(a)

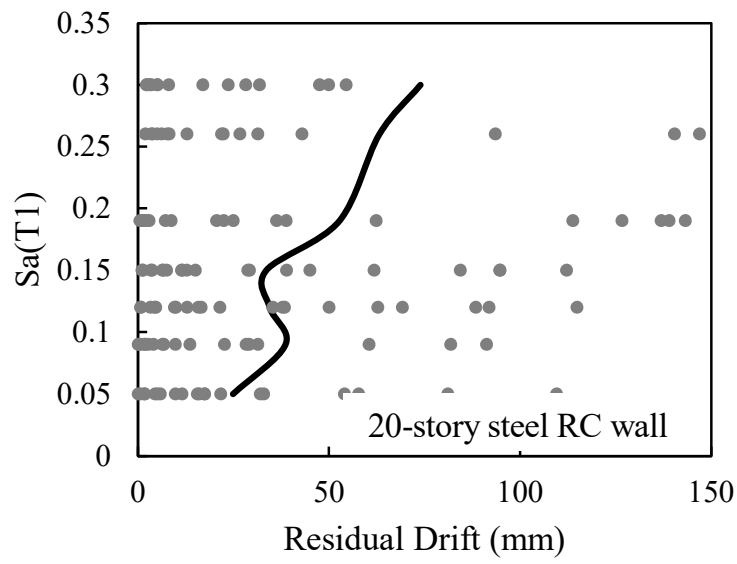

(c)

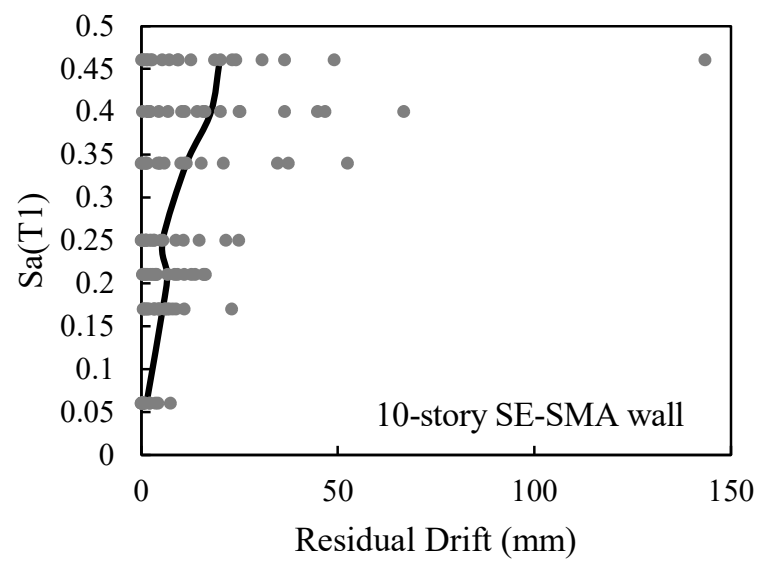

(b)

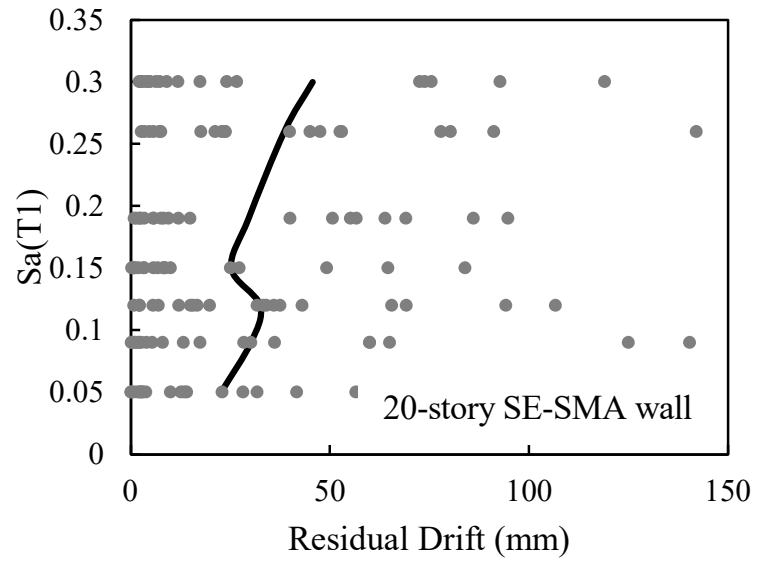

(d)

Figure 13. Maximum residual drift as function of ground motion intensity: (a) 10-story steel RC wall; (b) 10-story SE-

SMA RC wall; (c) 20-story steel RC wall; (d) 20-story SE-SMA RC wall

Table 4. Mean inter-story drifts and residual drifts

\begin{tabular}{c|c|c|c|c|c|c|c|c}
\hline \multirow{2}{*}{$\begin{array}{c}\text { Event } \\
\text { (years) }\end{array}$} & \multicolumn{3}{|c|}{ Steel } & \multicolumn{4}{c}{ 20-story } & \multicolumn{2}{c}{ Steel } & \multicolumn{2}{c}{ SE-SMA } \\
& ID (\%) & RD (\%) & ID (\%) & RD (\%) & ID (\%) & RD (\%) & ID (\%) & RD (\%) \\
\hline 2475 & 3.07 & 0.23 & 3.74 & 0.072 & 2.72 & 0.13 & 2.82 & 0.08 \\
1462 & 2.69 & 0.18 & 3.20 & 0.071 & 2.77 & 0.11 & 2.90 & 0.07 \\
975 & 2.28 & 0.10 & 2.84 & 0.054 & 1.93 & 0.095 & 1.95 & 0.053 \\
475 & 1.63 & 0.034 & 1.43 & 0.025 & 1.52 & 0.060 & 1.71 & 0.049 \\
336 & 1.52 & 0.050 & 1.60 & 0.030 & 1.26 & 0.063 & 1.36 & 0.060 \\
224 & 1.36 & 0.035 & 1.49 & 0.025 & 1.00 & 0.069 & 1.12 & 0.054 \\
72 & 0.40 & 0.004 & 0.40 & 0.003 & 0.48 & 0.039 & 0.46 & 0.04 \\
\hline
\end{tabular}


The collapse fragility curve, which shows the collapse probability as a function of ground motion intensity (Sa), is provided in Figure 14a. The fragility function fitting method proposed by Baker [40] is used to generate the fragility curves. At low levels of seismic excitations, a significant reduction in wall fragility is observed for walls reinforced with SE-SMA bars. The collapse probabilities at $S_{a}$ of $0.46 \mathrm{~g}$ for the 10 -story steel $\mathrm{RC}$ wall and $0.3 \mathrm{~g}$ for the 20 -story steel $\mathrm{RC}$ wall reach $80 \%$ and $73 \%$, respectively. Utilizing SE-SMA bars at wall boundaries in the plastic hinge zones significantly diminishes the collapse probability of the 10 and 20 -story walls by $66 \%$ and $50 \%$, respectively. The effect of using SE-SMA bars is more pronounced for the 10-story wall. However, the considered walls reach the same probability of collapse at seismic intensity of about $0.65 \mathrm{~g}$, which is significantly higher than the spectral acceleration of the maximum considered earthquake.

The fragility curves for the considered walls as a function of the maximum inter-story drift ratio (ID) are shown in Figure 14b. The 10 and 20-story steel RC walls have similar probabilities of collapse. The 10 and 20-story SE-SMA RC walls exhibit lower probability of collapse compared to the steel $\mathrm{RC}$ walls.

The probability of collapse against the roof residual drift ratio (RRD), which is normalized by the maximum residual drift is presented in Figure 14c. The probability of collapse is negligible for RRD less than or equal 0.3 . At RRD of 1.0, the 10 -story and 20 -story steel $\mathrm{RC}$ walls suffer major damage with a probability of collapse of about $80 \%$ and $73 \%$, respectively. The SE-SMA walls have significantly lower probability of collapse.

Results confirm the significance of considering both ID and RID when evaluating the SE-SMA RC wall fragility. At inter-story drift ratio of $2.4 \%$, both buildings exhibit the same fragility of collapse; 
whereas, the dispersion of fragility results between the SE-SMA and steel building is large at different RID ratio levels.

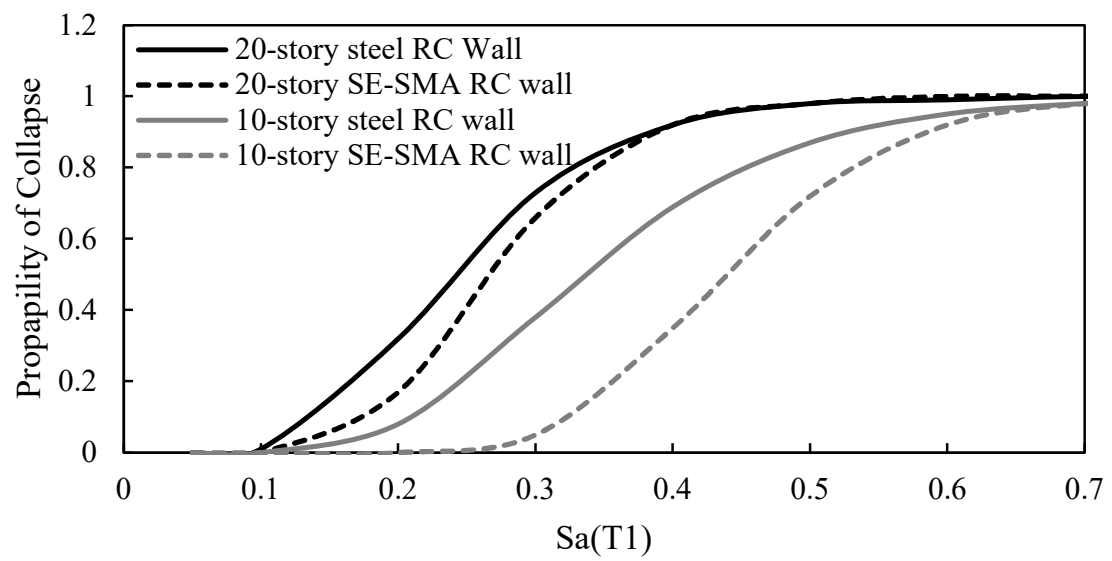

(a)

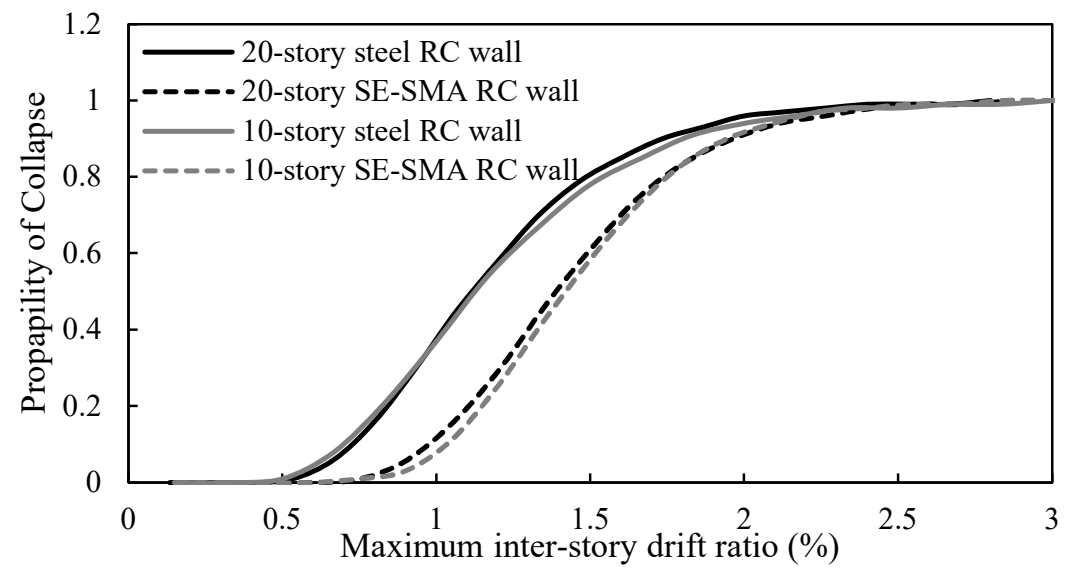

(b)

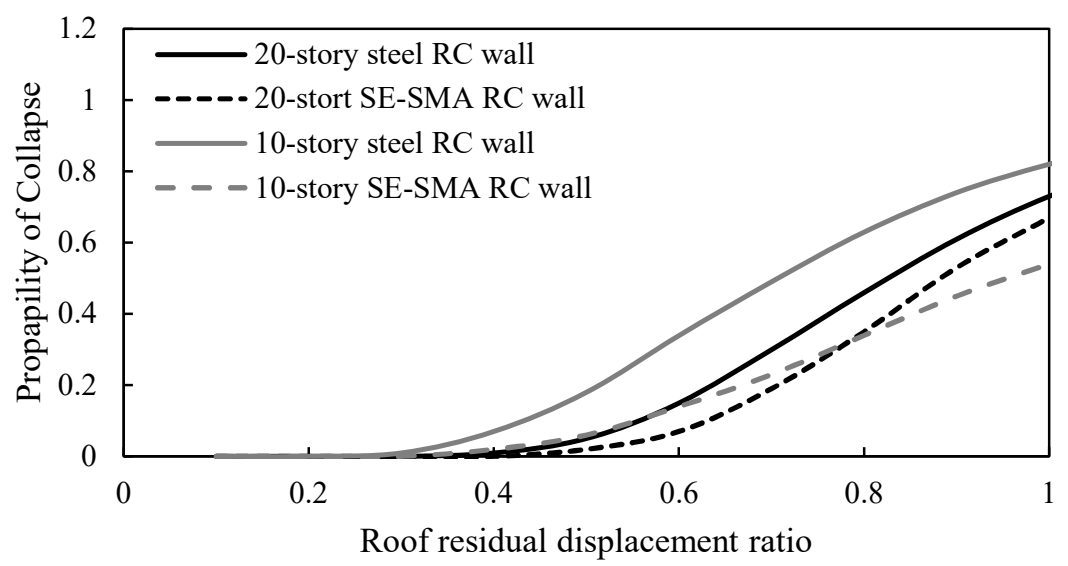

(c)

Figure 14. Collapse fragility curves with respect, to (a) Spectra acceleration; (b) Maximum inter-story drift ratio; (c) roof residual displacement ratio 


\section{CONCLUSIONS}

This paper investigates the effect of utilizing SE-SMA bars in RC shear walls designed according to the current Canadian design standards. The strain profile along the height of 10 and 20 -story steel RC walls revealed two plastic hinges at the base and at the mid-height sections. The length of each plastic hinge is about $20 \%$ of the wall's height. At these plastic hinge regions, steel bars within the boundary elements were replaced with SE-SMA bars. The seismic performance of the 10 and 20-story steel and SE-SMA RC walls is then compared using multi-hazard dynamic analysis. Conclusions of this paper are listed below.

1. The use of SE-SMA bars at the wall plastic hinges improved the seismic performance over steel $\mathrm{RC}$ walls. This improvement was characterized by lower shear forces and bending moments and reduced residual displacements (42\% average reduction). This improvement needs to be confirmed for shear walls with other heights and for other seismic ground motions.

2. Although the steel RC walls perform well under low probability seismic events, SE-SMA RC walls have significantly reduced permanent lateral deformations.

3. The efficiency of SE-SMA RC walls to recover the inter-story drifts is reduced for low-intensity seismic events and higher walls.

4. The dispersion of fragility results associated with residual drifts is considerably larger than the dispersion of fragility results associated with inter-story drifts. Hence, fragility results relying on inter-story drifts cannot be used to assess damage state in steel versus SE-SMA RC walls.

5. Steel RC walls exhibit higher fragility than SE-SMA RC walls in terms of residual drifts. This renders SE-SMA RC walls as less vulnerable to seismic damage. However, a negligible difference exists between steel and SE-SMA walls in term of inter-story drifts. 
6. The used analytical model accurately predicts the wall response for the steel RC wall and the SE-SMA RC wall. However, future studies to improve the accuracy of the analytical model are needed. This includes accounting for bond slip between SMA bars and mechanical couplers.

7. Additional experimental studies are needed to confirm results of this research. Also, future studies should account for the vertical ground excitation.

\section{REFERENCES}

[1] R. Su, S. M. Wong, Seismic behaviour of slender reinforced concrete shear walls under high axial load ratio, Eng. Struct. 29(8) (2006) 1957-1965.

[2] P. Riva, A. Meda, E. Giruriani, Cyclic behaviour of a full scale RC structural wall, Eng. Struct. 25(6) (2003) 835-845.

[3] N. Ganesan, R. Abraham, P. Beena, R. Anil, Influence of horizontal reinforcement on ultra high performance concrete wall panels under two way in plane action, International. J. Scientific \& Eng. Research. 4(5) (2013) 149-152.

[4] J. Aguilar, H. Juarez, R. Ortega, J. Iglesias, The Mexico earthquake of September 19,1985-statistics of damage and of retrofitting techniques in reinforced concrete buildings affected by the 1985 earthquake, Earthq. Spectra. 5(5) (1989) 145-151.

[5] K. C. Tsai, P. H. Chiang, M. Bruneau, Overview of building damages in 921 Chi-Chi Earthquake, Earthq. Eng \& Eng. Seismology. (2000) 2(1).

[6] B. Westenenk, J. C. de la Llera, J. J. Besa, R. Jünemann, J. Moehle, C. Lüders, J. A. Inaudi, K. J. Elwood, S. Hwang, Response of reinforced concrete buildings in Concepción during the Maule earthquake. Earthq. Spectra. 28(S1) (2012) S257-S280. 
[7] K. J. Elwood, S. Pampanin, W. Y Kam, 22 February 2011 christchurch earthquake and implications for the design of concrete structures in: Proceedings of the International Symposium on Engineering Lessons Learned from the 2011 Great East Japan Earthquake, Tokyo, Japan. 2011. 1157-1168.

[8] FEMA (Federal Emergency Mangement Agency). Seismic performance assessment of buildings: volume 1-methodolgy, FEMA P-58-1, Washington, DC, 2012.

[9] J. McCormick, H. Aburano, M. Ikenaga, M. Nakashima, Permissible residual deformation level for building structures considering both safety and human elements. In: Proceedings of the 14th World Conference on Earthquake Engineering, Beijing, China. Paper ID 05-06-0071, 2008.

[10] A. Belleri,, M. J. Schoettler, J. I. Restrepo, R. B. Fleischman, Dynamic behavior of rocking and hybrid cantilever walls in a precast concrete building, ACI. Struct. J, 111(3) (2014) 661-672.

[11] H. Buddika, A. Wijeyewickrema, Seismic performance evaluation of posttensioned Hybrid-precast wall-frame buildings and comparison with shear wall-frame buildings, ASCE J. Struct. Eng, 142(6) (2016) 1-14.

[12] T. Guo, GD, Zhang, C, Chen, Experimental study on self-centering concrete wall with distributed friction devices, J. Earthq. Eng. 18(2) (2014) 214-230.

[13] S. Saiidi, M. O’Brien, M. Sadrossadat-Zade,, Cyclic response of concrete bridge column using superelastic Nitinol and Bendable concrete, ACI Struct. J, 106(1) (2008) 69-77.

[14] M. Tazarv, S. M. Saiidi, Analytical studies of the seismic performance of a full-scale SMA-reinforced bridge column, International. J. Bridge. Eng. 1(1) (2013) 37-50.

[15] M. A. Youssef, M. S. Alam, M. Nehdi, Experimental investigation on the seismic behaviour of beamcolumn joints reinforced with superelastic shape memory alloys, J. Earthq. Eng. 12(7) (2008) 12051222.

[16] M. Alam, M. A. Youssef, M. Nehdi, Analytical prediction of the seismic behaviour of superelastic shape memory alloy reinforced concrete elements, Eng. Struct. 30(12) (2008) 3399-3411.

[17] M. A. Youssef, M. A. Elfeki, Seismic performance of concrete frames reinforced with superelastic shape memory alloys, Smart. Struct \& Systems. 9(4) (2012) 313-333. 
[18] M. A. Elfeki, M. A. Youssef, Shape memory alloy reinforced concrete frames vulnerable to strong vertical excitions, J. Building. Eng. (13) (2017) 272-290.

[19] E. Effendy, W. Liao, W. Song, M. Y. Loh, Seismic behaviour of low rise shear walls with SMA bars. engineering, construction, and operations in challenging environment, Houston, TX. 1-8, 2006.

[20] A, Abdulridha, Performance of superelastic shape memory alloy reinforced concrete elements subjected to monotonic and cyclic loading (Ph.D thesis), University of Ottawa, Ottawa, Canada, 2012.

[21] E. Abraik, M. A. Youssef, Cyclic performance of shape memory alloy reinforced concrete walls, in: Response of Structures Under Extreme Loading. The Fifth International Workshop on Performance, Protection, and Strengthening of Structures under Extreme Loading, Lansing, MI, USA, 2015.

[22] A23.3-14, Design of concrete structures. Canadian Standards Association, Mississauga, ON, Canada, 2015.

[23] The national Building Code of Canada: Canadian Commission on Building and Fire Codes, Ottawa: National Research Council, 2015.

[24] OpenSees, Open system for earhquake engineering simulation, Available from URL: 〈http://www. http://opensees.berkeley.edu//.

[25] K. Kolozvari, Analytical modeling of cyclic shear-flexural interaction in reinforced concrete structural walls, (Ph.D. Thesis), University of California Los Angeles, California, USA, 2013.

[26] K. Orakcal, J. W. Wallace, Nonlinear modeling and analysis of reinforced concrete structural walls, ACI Struct. J. 101(5) (2004) 688-698.

[27] M. Menegotto, P. Pinto, Method of analysis of cyclically RC plane frames including channges in geometry and non-elastic behavior of elements under normal force and bending. Proceedings of IABSE Symposium on Resistance and Ultimate Deform ability of Structures Acted On by Well Defined Repeated Loads, 11 (1973)15-22.

[28] G. Chang, J. Mander, Seismic energy based fatigue damge analysis of bridge columns: Part I-evaluation of seismic capacity. Buffalo, New York: State University of New York, 1994. 
[29] S. Varela, S. M. Saiidi, Dynamic performance of novel bridge columns with superelastic CuAlMn shape memory and ECC, International. J. Bridge. Eng. 2(3) (2014) 29-58.

[30] I. Ghorbanirenani, R. Tremblay, P. Léger, M. Leclerc, Shake table testing of slender RC shear walls subjected to Eastern North America seismic ground motions, ASCE J. Struct. Eng. 138(12) (2012) 1515-1529.

[31] The national Building Code of Canada: Canadian Commission on Building and Fire Codes, National Research Council,Ottawa, Canada, 2005.

[32] M, Panagiotou, Seismic design, testing and analysis of reinforced concrete wall buildings (Ph.D thesis), UC San Diego, San Diego, USA, 2008.

[33] M. Priestley, G. Calvi, M. Kowalsky, Displacement based seismic design of structures. IUSS Press. Pavia, Italy, 2007.

[34] M. Panneton, P. Léger, R. Tremblay, Inelastic analysis of a reinforced concrete shear wall building according to the National Building Code of Canada, Canadian J. of Civil. Eng. 33 (2006) 854-871.

[35] J. W. Baker, Conditional mean spectrum: tool for ground motion selection, J. Struct. Eng. 137(3) (2011) 322-331.

[36] P. C. Brown, Probabilistic earthquake damage prediction for reinforced concrete building components (M.S. Thesis), University of Washington, Seattle, USA, 2008.

[37] K. Kinali, B. R. Ellingwood, Seismic fragility assessment of steel frames for consequence-based engineering: A case study for Memphis, TN, Eng. Struct. 29(6) (2007) 1115-1127.

[38] J. W. Baker, Efficient analytical fragility function fitting using dynamic structural analysis. Earthq. Spectra, 31(1) (2015) 579-600.

[39] D. Vamvatsikos, C. A. Cornell, Applied incremental dynamic analysis, Earthq. Spectra. 20(2) (2004) 525553.

[40] J. W. Baker, C. A. Cornell, A vector-valued ground motion intensity measure consisting of spectral acceleration and epsilon, Earthq. Eng \& Struct. Dynamics. 34(10) (2005) 1193-1217. 


\section{NOMENCLATURE}

\begin{tabular}{|c|c|}
\hline CMS & Conditional mean spectra \\
\hline$A_{g}$ & Cross section area \\
\hline$f_{c}^{\prime}$ & Concrete compressive strength \\
\hline$R_{0}$ & Ductility factor \\
\hline$M_{f}$ & Factored moment \\
\hline$M_{r}$ & Factored moment resistance \\
\hline$l_{b l}$ & Length of wall boundary element \\
\hline$\theta$ & Median of the fragility function \\
\hline$I M$ & Ground motion intensity \\
\hline$\rho_{h w}$ & Horizontal steel ratio in the web \\
\hline$\rho_{h b}$ & Horizontal steel ratio in the boundaries \\
\hline ID & Inter-story drift \\
\hline MSA & Multi strip analysis \\
\hline $\mathrm{n}$ & Number of ground motions considered \\
\hline M & Number of intensity measure levels \\
\hline $\mathrm{P}$ & Probability of exceeding a damage level \\
\hline RDD & Residual displacement ratio \\
\hline $\mathrm{x}$ & Realized condition of the ground motion intensity measure \\
\hline $\mathrm{RC}$ & Reinforced concrete \\
\hline SE-SMA & Superelastic shape memory alloy \\
\hline$\varepsilon_{y}$ & Steel yield strain \\
\hline
\end{tabular}




$\begin{array}{ll}\Phi & \text { Standard normal cumulative distribution } \\ C & \text { Specific damage level } \\ S_{a} & \text { Spectra acceleration } \\ \beta & \text { Standard deviation } \\ R_{0} & \text { Overstrength factor } \\ \rho_{v w} & \text { Vertical steel ratio in the web } \\ \rho_{v b} & \text { Vertical steel ratio in the boundaries } \\ b_{w} & \text { Wall thickness } \\ l_{w} & \text { Wall length } \\ \mathrm{H} & \text { Wall height }\end{array}$

